\title{
Polyphenol Consumption and Metabolic Diseases
}

\section{Gulcin Sagdicoglu Celep ${ }^{1 *}$ and Reza Rastmanesh ${ }^{2}$}

${ }^{1}$ Industrial Arts Education Faculty, Family and Consumer Sciences, Food and Nutrition Technology, Gazi University, Ankara, Turkey ${ }^{2}$ Department of Human Nutrition and Dietetics, Shahid Beheshti University of Medical Sciences, Tehran, Iran

\section{Polyphenols}

Polyphenols are regular components of human diet and are associated with several beneficial health effects [1]. Many polyphenols have been identified in plants which are classified as flavonoids, phenolic acids, stilbenes and lignans depending on their chemical structures [2]. They possess several biological activities including antioxidant, antibacterial, antiviral, immunomodulatory, antiinflammatory, antiallergic, antimutagenic, antiviral, antineoplastic, antithrombotic, and vasodilatory activities $[3,4]$. The most prominent activity of polyphenols is expressed to be their antioxidant activities againts oxidative stress related with their ability to scavenge hydroxyl radicals, superoxide anions, and lipid peroxy radicals $[5,6]$.

\section{Common Sources and Dietary Intake of Polyphenols}

The main sources of polyphenols in the diet are fruits and beverages such as tea, coffee and wine [5]. Chocolate with its high flavonoids content $[7,8]$ along with vegetables, cereals and legume seeds also contribute to polyphenol intake.The total daily intake of polyphenols is estimated to be around $150-1000 \mathrm{mg}[9,10]$.

Polyphenols have an enormous variability in their structure, consequently in their function. Currently, more than 8000 phenolic structures have been identified in plants [11]. They usually occur as glycosides in the plants [9].

Among the common polyphenols in human diet, quercetin, kaempferol, myricetin and isorhamnetin are present in onions, apples, and tea $[12,13]$. Apigenin and luteolin can be found in celery, parsley, and artichoke in high amounts [14]. Catechins and procyanidins are found in red wine, grapes, tea and cocoa. Naringenin and hesperetin are the common polyphenols of citrus fruits. Anthocyanins are also important dietary flavonoids. Resveratrol (3,5,4 u-trihydroxystilbene) can be found in grapes, peanuts and also in berries, red cabbage and spinach [15].

\section{Benefits of Polyphenol Consumption}

Epidemiological studies have revealed that there are strong associations between the consumption of polyphenols and prevention of certain metabolic diseases. Oxidative damage is implicated in a number of diseases including cancer, cardiovascular and neurodegenerative diseases and polyphenols act in these cases as antioxidants with different mechanisms of actions. The role of free radicals, including the superoxide radical $\left(\mathrm{O}_{2}^{-}\right)$, hydroxyl radical $(. \mathrm{OH})$, hydrogen peroxide $\left(\mathrm{H}_{2} \mathrm{O}_{2}\right)$, and lipid peroxide radicals have been implicated in cancer [16], cardiovascular disease [7,8], diabetes [17], gastrointestinal inflammatory diseases [18], liver disease [19], and also in aging [20,4].

Catechin and its derivatives, oligomeric proanthocyanidins, quercetin and quercetin chalcone, ginkgo polyphenols, silymarin, and others can be utilized in preventative and treatment protocols for cardiovascular disease, cancer, and liver diseases [4]. Regular consumption of isoflavones such as genistein found in soy reduced arteriosclerosis and certain cancers since they have the capability to act as phytoestrogens [21].

The prevalence of obesity and related metabolic complications with morbidity has increased dramatically in recent years [22]. Diabetes and obesity are major risk factors for cardiovascular diseases, several forms of cancer (such as colon and prostate) and metabolic diseases [23,24]. High polyphenol and selectively-restricted probiotic diet is proposed as a regimen by nutritionists for maintaining normal body weight [25] and this type of diet has attracted great attention recently.

The anti-obesity effect of green tea catechins is particularly attributed to Epigallocatechin Gallate (EGCG), which exhibits its antiobesity effects through suppression of adipocyte differentiation and proliferation, inhibition of fat absorption from the gut, and suppression of catechol-o-methyltransferase (COMT) enzyme that inhibits fatty acid oxidation in brown adipose tissue [26].

The administration of purified anthocyanins from blueberries were reported to lower serum triglycerides, cholesterol and leptin levels. Different mechanisms were suggested to explain the effects of polyphenols on the lipid metabolism however the exact mechanisms are still unknown [26].

Dietary polyphenols, have antioxidant and anti-inflammatory properties via modulating different pathways, such as NF-kB- [27], mitogen activated protein kinase-dependent signaling pathways and thereby regulating metabolism, stress resistance, cellular survival, cellular senescence/aging, inflammation-immune function. Resveratrol has been suggested to increase glucose uptake through up-regulation of estrogen receptor- $\alpha$, and increase GLUT 4 expression through phosphatidylinositol-3 kinase and AKT pathway. Through up-regulation of SIRT 1, resveratrol is denoted to help mitochondrial biogenesis, oxidative phosphorylation, and suppress lipid accumulation $[28,29]$.

Inflammation is a free radical involved process. The enzymes cyclooxygenase and lipoxygenase which oxidize arachidonic acid in cell membranes form potent pro-inflammatory metabolites, including prostaglandins, leukotrienes, and thromboxanes. Polyphenols quercetin, rutin, kaempferol, curcumin, and silymarin exhibit inhibition of cyclooxygenase and lipoxygenase in vitro [30-32]. In addition, polyphenols can induce antioxidant enzymes such as glutathione peroxidase, catalase and superoxide dismutase which protect the cells by decomposing hydroperoxides, hydrogen peroxide and superoxide anions, respectively. They can also inhibit the expression of enzymes such as xanthine oxidase [33,34].

Polyphenols can also contribute to health by inhibiting the platelet aggregation where the 3,4-dihydroxyphenylacetic and 4-hydroxyphenylacetic acid metabolites were found to be more active than their precursors rutin or quercetin [35].

*Corresponding author: Gulcin Sagdicoglu Celep, Industrial Arts Education Faculty, Family and Consumer Sciences, Food and Nutrition Technology, Gazi University, Ankara, Turkey, E-mail: gulcin.celep@gmail.com

Received December 17, 2012; Accepted December 18, 2012; Published December 20, 2012

Citation: Celep GS, Rastmanesh R (2013) Polyphenol Consumption and Metabolic Diseases. J Nutr Disorders Ther 3:e106. doi:10.4172/2161-0509.1000e106

Copyright: $\odot 2013$ Celep GS, et al. This is an open-access article distributed under the terms of the Creative Commons Attribution License, which permits unrestricted use, distribution, and reproduction in any medium, provided the original author and source are credited. 
Polyphenols concentrations in plasma are low as usually less than $1 \mu \mathrm{mol} / \mathrm{L}$ in part because of rapid metabolism by human tissues [6] so the activities of the metabolites gain important attention to reveal the beneficial effects of polyphenols. Understanding the mechanisms of actions of polyphenols and their metabolites either as antioxidants or modulators of cell signaling will help to evaluate the modulators in metabolic diseases [36,37]. The metabolites formed in the small intestine and hepatic cells, and low molecular weight catabolic products produced by the colonic microflora carries critical interest for drug discovery and also for dietary prevention of disease including metabolic diseases [38].

\section{Conclusion}

It is important to unravel the complex biological activities of polyphenols and their metabolites using in vitro and in vivo studies to better understand their benefits for human health.

\section{References}

1. van Duynhoven J, Vaughan EE, Jacobs DM, Kemperman RA, van Velzen EJ, et al. (2011) Metabolic fate of polyphenols in the human superorganism. Proc Natl Acad Sci U S A 108: 4531-4538.

2. Manach C, Scalbert A, Morand C, Rémésy C, Jiménez L (2004) Polyphenols: food sources and bioavailability. Am J Clin Nutr 79: 727-747.

3. Vauzour D, Rodriguez-Mateos A, Corona G, Oruna-Concha MJ, Spencer JP (2010) Polyphenols and human health: prevention of disease and mechanisms of action. Nutrients 2: 1106-1131.

4. Miller AL (1996) Antioxidant Flavonoids: Structure, Function and Clinical Usage. Alternative Medicine Review 1: 103-111.

5. Scalbert A, Morand C, Manach C, Rémésy C (2002) Absorption and metabolism of polyphenols in the gut and impact on health. Biomed Pharmacother 56: 276 282.

6. Pannala AS, Rice-Evans CA, Halliwell B, Singh S (1997) Inhibition of peroxynitrite-mediated tyrosine nitration by catechin polyphenols. Biochem Biophys Res Commun 232: 164-168.

7. Fraga CG (2005) Cocoa, diabetes, and hypertension: should we eat more chocolate? Am J Clin Nutr 81: 541-542.

8. Litterio MC, Jaggers G, Sagdicoglu Celep G, Adamo AM, Costa MA, et al. (2012) Blood pressure-lowering effect of dietary (-)-epicatechin administration in L-NAME-treated rats is associated with restored nitric oxide levels. Free Radic Biol Med 53: 1894-1902.

9. Scalbert A, Williamson G (2000) Dietary intake and bioavailability of polyphenols. J Nutr 130: 2073S-2085S.

10. Stahl W, van den Berg H, Arthur J, Bast A, Dainty J, et al. (2002) Bioavailability and metabolism. Mol Aspects Med 23: 39-100.

11. Cheynier V (2005) Polyphenols in foods are more complex than often thought. Am J Clin Nutr 81: 223S-229S.

12. Hertog MGL, Hollman PCH, Katan MB (1992) Content of potentially anticarcinogenic flavonoids of 28 vegetables and 9 fruits commonly consumed in the Netherlands. J Agric Food Chem 40: 2379-2383.

13. Hodgson JM, Croft KD (2006) Dietary flavonoids: effects on endothelial function and blood pressure. J Sci Food Agric 86: 2492-2498.

14. Jaganath IB, Crozier A (2010) Dietary flavonoids and phenolic compounds. Plant Phenolics and Human Health: Biochemistry, Nutrition, and Pharmacology.

15. Burns J, Yokota T, Ashihara H, Lean ME, Crozier A (2002) Plant foods and herbal sources of resveratrol. J Agric Food Chem 50: 3337-3340.
16. Ginter E (1995) The role of antioxidants in the prevention of tumors. Bratisl Lek Listy 96: 195-209.

17. Kähler W, Kuklinski B, Rühlmann C, Plötz C (1993) Diabetes mellitus--a free radical-associated disease. Results of adjuvant antioxidant supplementation. $Z$ Gesamte Inn Med 48: 223-232.

18. Yoshikawa T, Naito $Y$, Kondo M (1993) Antioxidant therapy in digestive diseases. J Nutr Sci Vitaminol (Tokyo): S35-S41.

19. Miguez MP, Anundi I, Sainz-Pardo LA, Lindros KO (1994) Hepatoprotective mechanism of silymarin: no evidence for involvement of cytochrome P450 2E1. Chem Biol Interact 91: 51-63.

20. Queen BL, Tollefsbol TO (2010) Polyphenols and aging. Curr Aging Sci 3: 34 42.

21. Wuttke W, Jarry H, Seidlová-Wuttke D (2007) Isoflavones--safe food additives or dangerous drugs? Ageing Res Rev 6: 150-188.

22. Mokdad AH, Bowman BA, Ford ES, Vinicor F, Marks JS, et al. (2001) The continuing epidemics of obesity and diabetes in the United States. JAMA 286: 1195-1200.

23. Field AE, Coakley EH, Must A, Spadano JL, Laird N, et al. (2001) Impact of overweight on the risk of developing common chronic diseases during a 10year period. Arch Intern Med 161: 1581-1586.

24. http: //eprints.ucl.ac.uk/4841/1/4841.pdf

25. Rastmanesh R (2011) High polyphenol, low probiotic diet for weight loss because of intestinal microbiota interaction. Chem Biol Interact 189: 1-8.

26. Meydani M, Hasan ST (2010) Dietary polyphenols and obesity. Nutrients 2 : 737-751.

27. Mackenzie GG, Delfino JM, Keen CL, Fraga CG, Oteiza PI (2009) Dimeric procyanidins are inhibitors of NF-kappaB-DNA binding. Biochem Pharmaco 78: $1252-1262$.

28. Ahn J, Cho I, Kim S, Kwon D, Ha T (2008) Dietary resveratrol alters lipid metabolism-related gene expression of mice on an atherogenic diet. $\mathrm{J}$ Hepato 49: 1019-1028.

29. Floyd ZE, Wang ZQ, Kilroy G, Cefalu WT (2008) Modulation of peroxisome proliferator-activated receptor gamma stability and transcriptional activity in adipocytes by resveratrol. Metabolism 57: S32-S38.

30. Yoshimoto T, Furukawa M, Yamamoto S, Horie T, Watanabe-Kohno S (1983) Flavonoids: potent inhibitors of arachidonate 5-lipoxygenase. Biochem Biophys Res Commun 116: 612-618.

31. Stoner GD, Mukhtar H (1995) Polyphenols as cancer chemopreventive agents J Cell Biochem Suppl 22: 169-180.

32. Huang MT, Lysz T, Ferraro T, Abidi TF, Laskin JD, et al. (1991) Inhibitory effects of curcumin on in vitro lipoxygenase and cyclooxygenase activities in mouse epidermis. Cancer Res 51: 813-819.

33. Disilvestro RA (2001) Flavonoids as Antioxidants. In Handbook of Nutraceuticals and Functional Foods, CRC Press, Boca Raton, FL, USA.

34. Du Y, Guo H, Lou H (2007) Grape seed polyphenols protect cardiac cells from apoptosis via induction of endogenous antioxidant enzymes. J Agric Food Chem 55: 1695-1701.

35. Kim DH, Jung EA, Sohng IS, Han JA, Kim TH, et al. (1998) Intestinal bacterial metabolism of flavonoids and its relation to some biological activities. Arch Pharm Res 21: 17-23.

36. Williams RJ, Spencer JP, Rice-Evans C (2004) Flavonoids: antioxidants or signalling molecules? Free Radic Biol Med 36: 838-849.

37. Tsao R (2010) Chemistry and biochemistry of dietary polyphenols. Nutrients 2: $1231-1246$

38. Del Rio D, Costa LG, Lean ME, Crozier A (2010) Polyphenols and health: what compounds are involved? Nutr Metab Cardiovasc Dis 20: 1-6. 